\title{
What FutureCar MPG Levels and Technology Will Be Necessary?
}

\author{
Philip Patterson, Department of Energy \\ Elyse Steiner, National Renewable Energy Laboratory \\ Margaret Singh, Argonne National Laboratory
}

\begin{abstract}
The potential peaking of world conventional oil production and the possible imperative to reduce carbon emissions will put great pressure on vehicle manufacturers to produce more efficient vehicles, on vehicle buyers to seek them out in the marketplace, and on energy suppliers to develop new fuels and delivery systems.

Four cases for stabilizing or reducing light vehicle fuel use, oil use, and/or carbon emissions over the next 50 years are presented.

Case 1 - Improve mpg so that the fuel use in 2020 is stabilized for the next 30 years. Case 2 - Improve mpg so that by 2030 the fuel use is reduced to the 2000 level and is reduced further in subsequent years.

Case 3 - Case 1 plus $50 \%$ ethanol use and 50\% low-carbon fuel cell vehicles by 2050 . Case 4 - Case 2 plus $50 \%$ ethanol use and 50\% low-carbon fuel cell vehicles by 2050 . The mpg targets for new cars and light trucks require that significant advances be made in developing cost-effective and very efficient vehicle technologies. With the use of alternative fuels that are low in carbon, oil use and carbon emissions can be reduced even further.
\end{abstract}

\section{INTRODUCTION}

Of course, an answer to the question in this paper's title requires us to know "necessary for what"? Do we want to stabilize the absolute amount of fuel use? Reduce the amount of fuel used relative to today's consumption? Eliminate the use of petroleum altogether? Avoid the use of any fossil fuels? Reduce carbon emissions?

What are the implications if we do nothing to improve light vehicle fuel economy and to switch to alternatives to oil? This paper will attempt to answer these questions and provide an idea of how important increases in light vehicle fuel economy will be in the future.

\section{Fuel Supply Concerns}

There are strong indications that the U.S. transportation sector will have to transition away from its nearly complete dependence on oil within the next several decades. ${ }^{1}$ The amount of conventional oil that still remains in the ground is uncertain. But with the growing world demand for oil, the year at which world oil production will peak is 
probably between 2010 and 2030 . There are some predictions that world oil production will peak even before $2010 .{ }^{2}$ Figure 1 shows one estimate of when the world oil peak might occur. 
Figure 1: The World Oil Gap

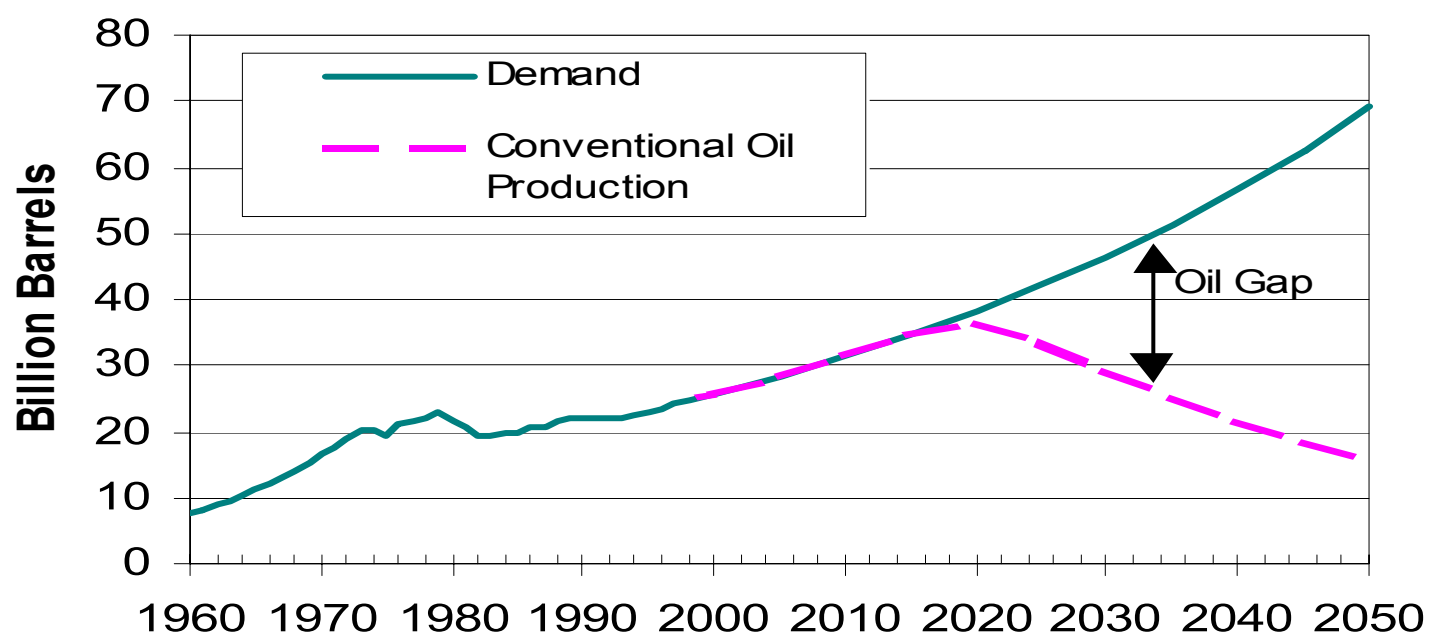

This graph shows the peaking of world conventional oil to occur around 2020. When the peak does occur, the market price of oil will begin to rise. As the remaining oil resources are consumed, the price of oil will rise so that oil will never be entirely "used up" or "depleted". Oil will become so expensive at some point before its exhaustion that other substitutes will come into play and largely displace it.

One of the potential alternative fuels in the U.S. is domestic natural gas. However, a preliminary investigation ${ }^{3}$ into the projected demand for natural gas by electric utilities and other end users has indicated that U.S. natural gas (both conventional and unconventional, but excluding hydrates) is likely to experience a peaking of its own in the 2020 to 2040 period. This is shown in Figure 2.

Figure 2: The Potential Gap for U.S. Natural Gas and a Peaking of Production in 2030

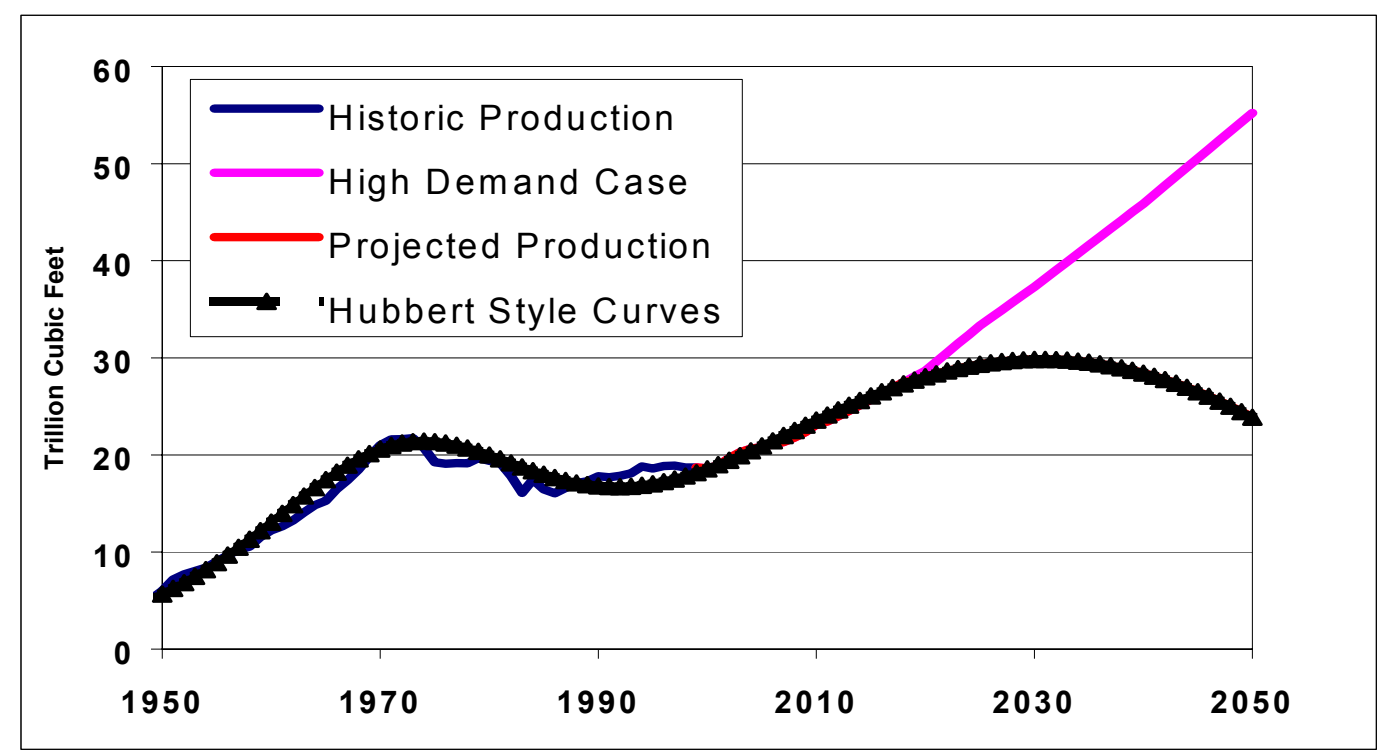


When the peaking of world oil and U.S. natural gas production are put on the same graph, the results shown in Figure 3 are obtained. One billion barrels of oil are equal to about six trillion cubic feet of natural gas.

\section{Figure 3: The Potential Peaking of World Oil and U.S. Natural Gas Production}

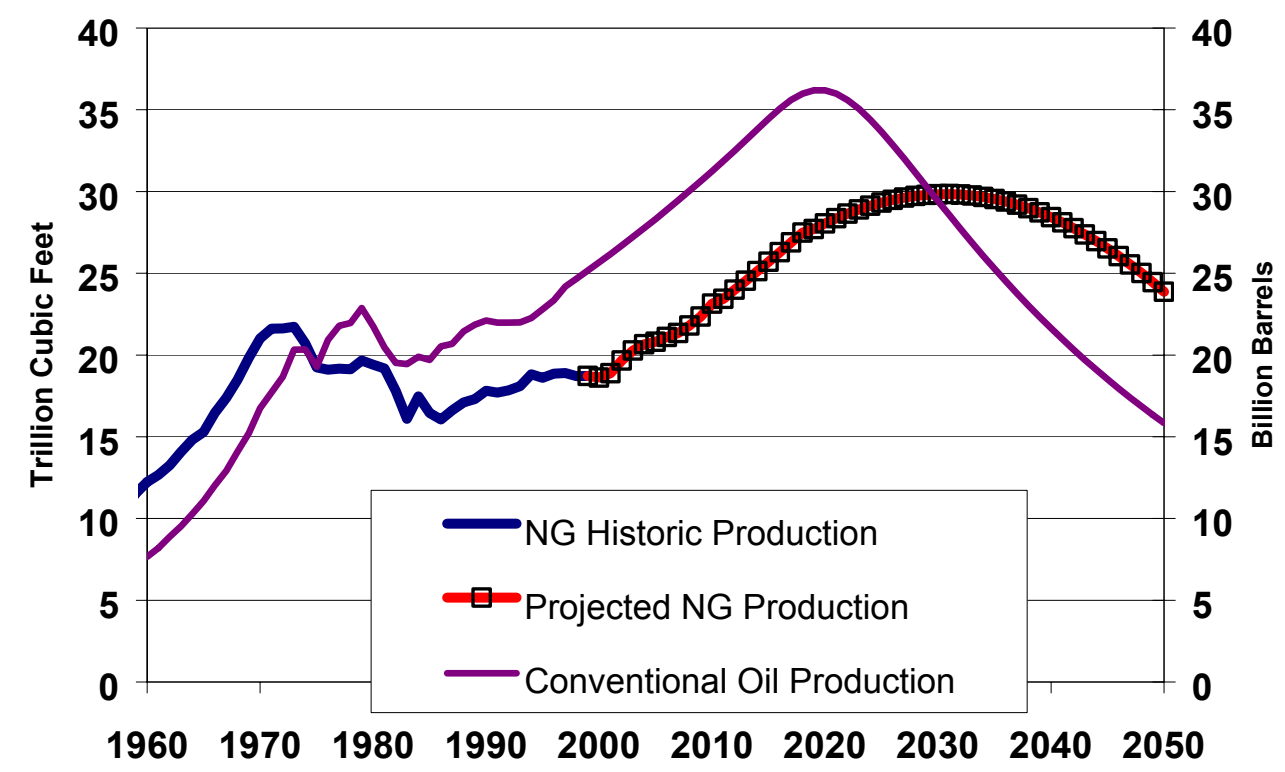

There may be plenty of natural gas elsewhere in the world to supply either natural gas (via LNG tankers) or petroleum-like products made from natural gas to the U.S. But these would be imported fuels that would still transfer wealth from the U.S. (if their price was artificially high due to cartel actions) and these products would probably come from Russia and/or OPEC countries, thus raising security concerns.

One of the strongest reasons for wanting to reduce the U.S. dependence on oil is that this dependence over the past 30 years has cost over $\$ 3$ trillion, undiscounted 1998 dollars, and over $\$ 7$ trillion when past losses are reckoned at their present value. ${ }^{4}$ The sources for these costs are roughly evenly divided among transfer of wealth from U.S. oil consumers to foreign oil producers, losses due to disruption of the economy caused by price shocks, and loss of GDP due to the higher prices for oil (as the result of cartel actions).

Figure 4 shows the percent of world oil production, oil reserves, natural gas reserves, and flared/vented natural gas that is in OPEC and OPEC+ (which adds Russia, Mexico, Norway, and Oman to the eleven OPEC countries). 
Figure 4: OPEC and OPEC+ Share of Oil and Natural Gas Reserves

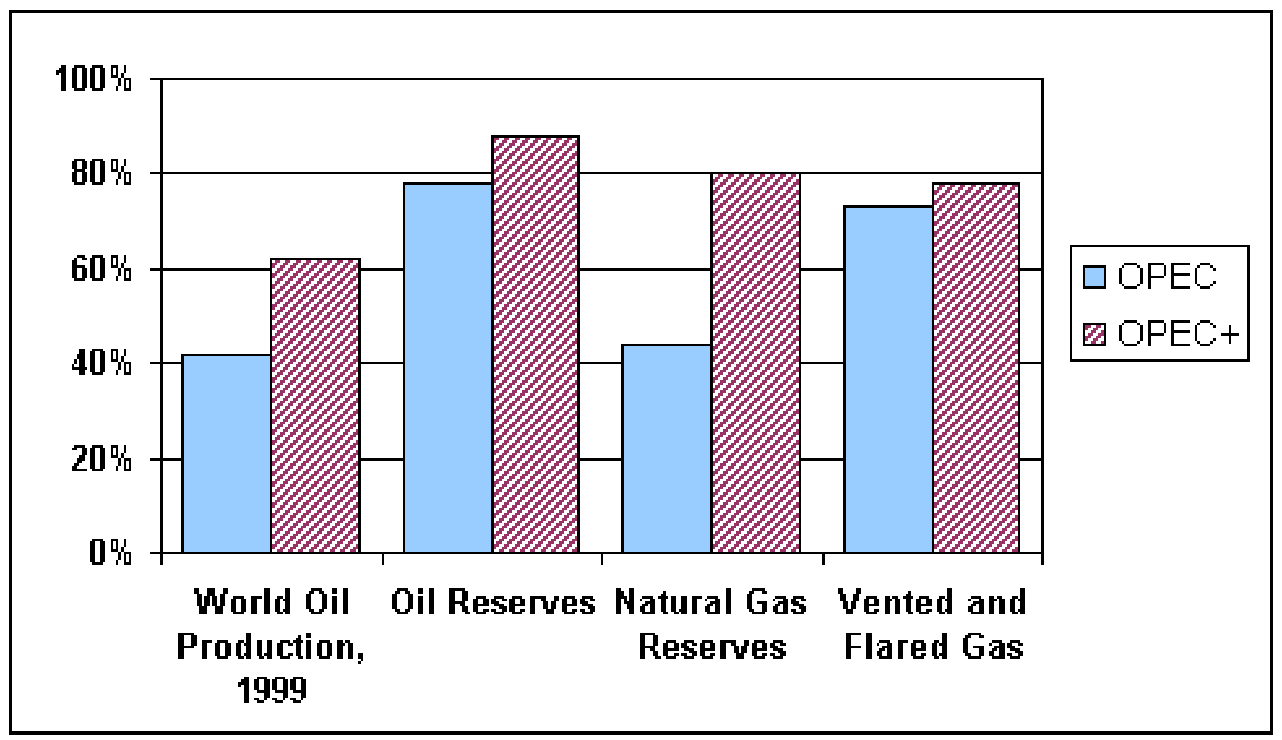

The reason these four countries are added to OPEC to get OPEC + is because they were the countries that in 1999 joined forces with the OPEC countries to reduce oil production to drive the world price of oil from $\$ 10$ a barrel to $\$ 30$ a barrel.

What other fuels might be available to supply the fuel demanded by light vehicles in the future? This paper will look at fossil liquids, biomass ethanol, and hydrogen (from several sources).

\section{Fossil Liquids}

A gasoline and/or diesel-like fuel can be produced from natural gas, coal, or unconventional petroleum resources. These three resources have world resource estimates about the same as for conventional oil or larger. However, each has a drawback to use as a resource fuel for transportation. If natural gas were the feedstock for fossil liquids, these liquids would probably be imported. This is because domestic natural gas is too expensive to provide a reasonably priced fossil liquid and it will become increasingly expensive once the production peak is reached. Most of the inexpensive natural gas will be in OPEC + countries. Therefore, it is possible that a cartel (which may be unreliable and a threat to U.S. energy security) will be in charge of the price and availability of internationally traded fossil liquids.

Coal-based liquids would avoid energy security concerns because they would be derived from domestic coal, but carbon emissions and the costs associated with reducing them are a significant concern. Estimates of unconventional petroleum resources in the form of heavy oil, tar sands and oil shale are many times larger than those of conventional oil resources. However, the environmental problems associated with producing liquids from them are substantial relative to those associated with production of conventional oil. 


\section{Biomass Ethanol}

There are several reasons for the growing interest and significant investment in developing ethanol fuels from biomass. The foremost reason is that bioethanol is a liquid transportation fuel made from plant matter instead of petroleum. Using biofuels reduces greenhouse gas emissions, dependence on imported oil, and the trade deficit, while stimulating local agriculture and rural economies in North America. Biomass ethanol is a very good carbon reducing fuel because the grasses and/or trees that are used to make the ethanol absorb about the same amount of carbon that the vehicles emit when they use the ethanol. Land is required to grow the biomass and the amount of land that will be available between now and 2050 for this purpose is highly uncertain. In gasoline equivalents, about 4 mbpd could be derived from the use of 42 million acres of cropland ( $20 \%$ of the cropland) and 200 metric tonnes of crop residue. ${ }^{5}$

Today, nearly all of the 1.6 billion gallons of ethanol produced in the U.S. during the year are sold blended with gasoline as a fuel additive, but the alternative fuel market is expected to grow over time with greater supply and more flex fuel vehicles on the road. Ethanol is made primarily from corn, but competing uses for the commodity make it relatively expensive as a biomass energy feedstock. In the future, an adequate supply of competitively priced biomass from other sources will be critical if ethanol is to play a significant role in the country's energy future. Alternative lignocellulosic resources will include forest residues, mill residues urban wood wastes, agricultural residues, and bioenergy crops.

\section{Hydrogen}

Hydrogen and oxygen fed into a proton exchange membrane (PEM) fuel cell "stack" is capable of producing enough electricity to power an electric automobile, without producing harmful emissions. Although no transportation distribution system exists today for hydrogen transportation use, the ability to produce the fuel from a variety of resources and its clean-burning properties make it an attractive alternative fuel.

Hydrogen is a carrier of energy that can be produced from virtually any energy resource and in unlimited quantities. In the near term, hydrogen will be produced in the U.S. from natural gas. But since this is not a sustainable way to produce large amounts of hydrogen in the future, three other resources are considered: coal with sequestration, nuclear, and renewable (wind, solar, and/or biomass).

The goal of the new FreedomCAR program announced by the U.S. Department of Energy in January 2002 is the development of emission- and petroleum-free cars and light trucks, targeted at impacting a variety of models. FreedomCAR focuses on the highrisk research needed to develop the necessary technologies, such as fuel cells and hydrogen from domestic renewable sources, to provide a full range of affordable cars and light trucks that are free of foreign oil and harmful emissions, without sacrificing freedom of mobility and freedom of vehicle choice. 


\section{New and On-Road MPG}

Due to the fact that new vehicles sales represent less than ten percent of the vehicle stock, there will be a substantial delay between initial deployment of a fuel-efficient vehicle and realization of energy saving benefits. Figures $5 \mathrm{a}$ and $5 \mathrm{~b}$ illustrate two deployment schemes for new vehicles with twice the fuel economy of current new vehicles.

Figure 5a: New Vehicle Fuel Economy

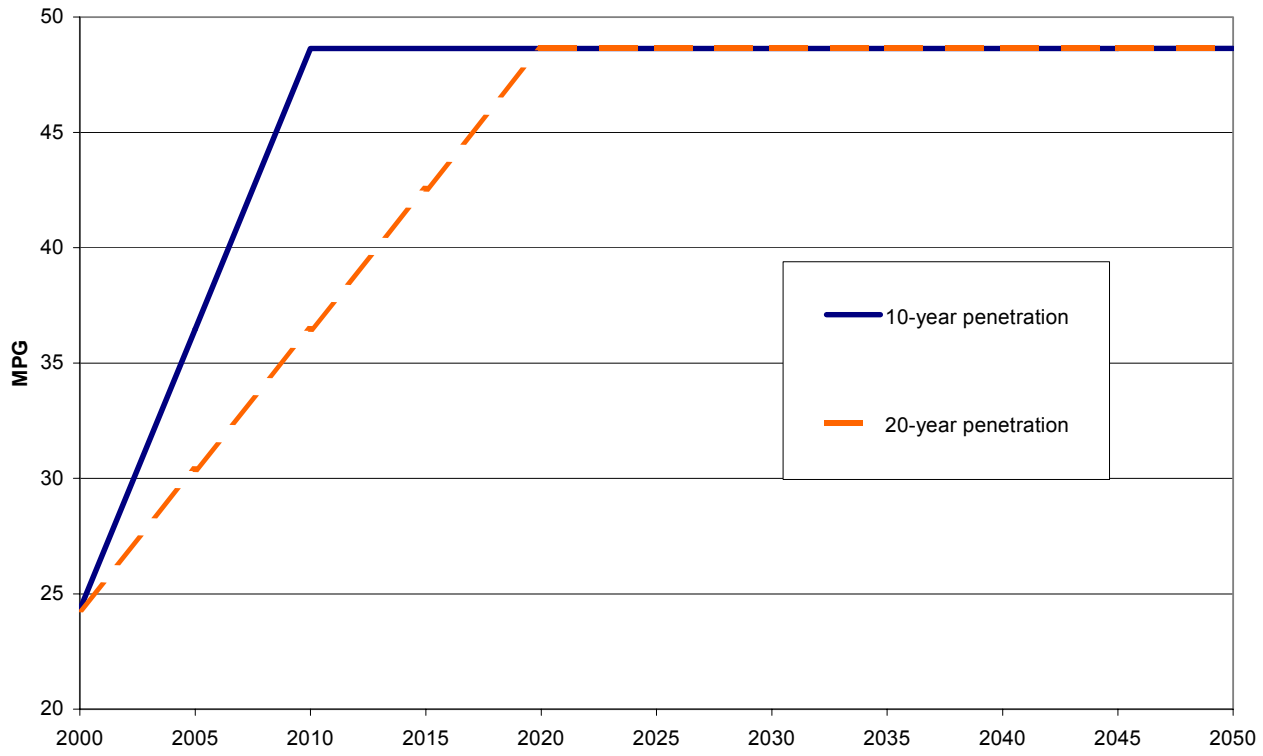


Figure 5b: Stock Fuel Economy

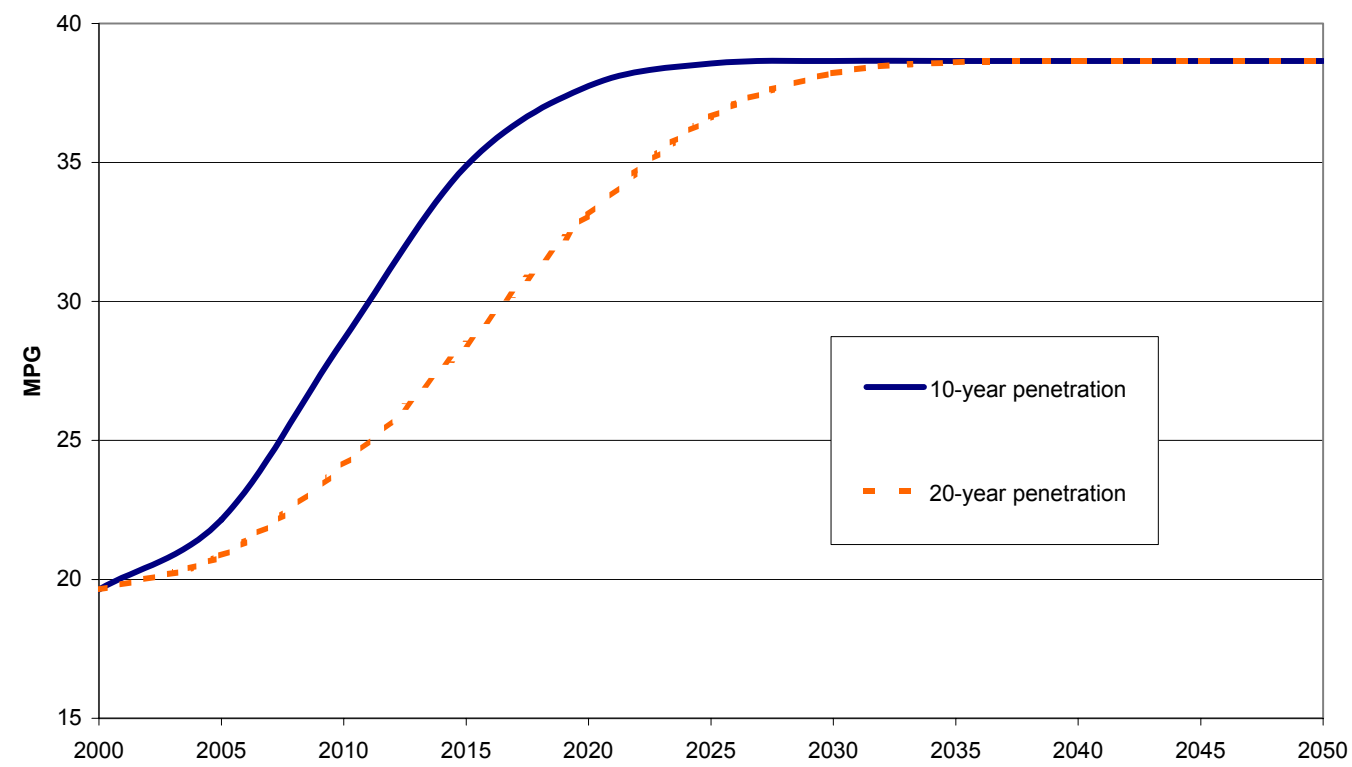

If the advanced vehicles follow a 10 -year market penetration curve, starting at $10 \%$ of the market in 2001 and reaching $100 \%$ by 2010, the on-road fuel economy of the stock would not double until about 2030. This aggressive deployment is somewhat more ambitious than recent history. Over a thirteen-year period between 1975 and 1988, the fuel economy of new cars sold in the U.S. increased by a factor of 1.8, and has held steady since. In the 25-year period since 1975, the on-road fuel economy of the automobile stock increased by a factor of 1.5 and has flattened out since new car mpg has not risen in the last 17 years. ${ }^{6}$ In the second deployment situation illustrated in Figure 1, the advanced vehicles take 20 years to penetrate $100 \%$ of the market, and the stock fuel economy takes 38 years to double.

\section{The Model}

This paper reports on the use of a spreadsheet model that estimates the energy demanded by U.S. cars and light trucks out to the year 2050. The VISION model was developed for the Office of Transportation Technologies (OTT) ${ }^{7}$ to examine the energy, oil, and carbon impacts from alternative assumptions with respect to the mpg levels for cars and light trucks. The model has six alternative vehicle types and six alternative fuel options. The user can specify fuel economy, vehicle-miles-of-travel (VMT) growth rates, and market penetration of alternative fuels. The model operates on an annual basis to 2050, and the summary tables show results at ten years intervals. 


\section{The Base Case}

In the Base Case, the fuel economy of new light vehicles remains at the 2000 level for the next 50 years. This causes the use of oil by these vehicles to rise from $7.6 \mathrm{mbpd}$ in 2000 to $17.9 \mathrm{mbpd}$ in 2050 due to increased VMT. This may be unrealistic, but it allows the calculation of oil reductions from specific gains in fuel economy over this period. However, the fuel economy of light vehicles has actually declined $1.7 \mathrm{mpg}$ since 1988 from 22.1 in 1988 to 20.4 in $2001^{8}$, so there is no guarantee that future mpg will rise. The Base Case fuel use growth over the next 50 years represents an annual growth rate of $1.7 \%$ which is substantially less than the nearly $3 \%$ annual rate of growth over the past 50 years. ${ }^{9}$

The carbon emissions from light vehicles grow from 364 mmtcfc (million metric tons of carbon on a fuel cycle basis) to 853 mmtcfc between 2000 and 2050. This level of carbon emissions in 2050 is larger than today's total carbon emission from every country except the U.S. and is about equal to the total carbon emissions from China (the second largest carbon emitting country today).

The Base Case projection assumes that VMT continues to grow but at a decreasing rate. Over the last 50 years, VMT grew at an annual rate of $3.6 \%{ }^{10}$ In this analysis, it is assumed that VMT grows at an annual rate of $2.35 \%$ between 2000 and $2010^{11}$, and at a lower rate in each succeeding decade, so that by the 2040 to 2050 period it grows by $1.3 \%$ per year. The VISION model allows the user to input a "rebound effect" that has VMT increase as the cost of travel declines due to more efficient vehicles. No rebound effect is represented in the runs used in this paper. If one wanted to use the estimated $20 \%$ rebound effect estimate ${ }^{12}$, the oil and carbon emissions savings due to efficiency improvements would be about $20 \%$ less.

The four alternatives to the Base Case are:

Case 1 - Improve mpg so that the fuel use in 2020 is stabilized for the next 30 years. Case 2 - Improve mpg so that by 2030 the fuel use is reduced to the 2000 level and is reduced further in subsequent years.

Case 3 - Case 1 plus 50\% ethanol use and 50\% low-carbon fuel cell vehicles by 2050 . Case 4 - Case 2 plus 50\% ethanol use and 50\% low-carbon fuel cell vehicles by 2050.

Cases 3 and 4 require the use of non-fossil fuels such a biomass ethanol and hydrogen and electricity generated from renewable sources such as wind, hydro, and solar and/or fossil fuels with carbon sequestration. Hydrogen fuel cell vehicles do not enter the market until 2010 in these cases. Fuel economy increases begin in 2005 in all four cases. The sales of new cars and light trucks are divided evenly (50/50) between the two categories.

\section{Case 1}

For the U.S. to stabilize the amount of energy used by light vehicles at a certain level, it would be necessary for fuel economy to continually improve to compensate for growing VMT. This case relies entirely on fuel economy improvements in conventional vehicles 
to avoid increases in oil use after 2020. No alternative fuel vehicles have been introduced in the market.

This case has new light vehicle fuel economy rise to $44.1 \mathrm{mpg}$ in 2050 , a gain of $81 \%$. Assuming that cars and light trucks have equal percentage gains in fuel economy, this means that new car mpg reaches 51.7 and light truck mpg reaches 38.4 in 2050. This results in $10.7 \mathrm{mbpd}$ (millions of barrels per day) of oil use in 2020 and beyond. The oil savings in 2050 compared to the Base Case is $7.2 \mathrm{mbpd}$.

This constant amount of light vehicle fuel use sets a target for alternative fuels to reach. If the alternative fuel comes with a technology that makes it more efficient (as might be the case with a fuel cell operating on hydrogen), the actual amount of energy needed will be less.

\section{Case 2}

In this case, fuel economy of light vehicles has to improve at a pace that brings total oil use in 2030 down to the 2000 level of oil use. This requires that new car mpg increase to $51.3 \mathrm{mpg}$ in 2030 and that it go even higher to $71.8 \mathrm{mpg}$ in 2050 . The $2030 \mathrm{mpg}$ value is $80 \%$ higher than today's level and the $2050 \mathrm{mpg}$ value is $150 \%$ higher. These are very large gains in fuel economy. Light truck mpg is 46.6 in 2030 and 55.1 in 2050.

By having oil use decline to $7.6 \mathrm{mbpd}$ in 2050 , over $10 \mathrm{mbpd}$ is saved relative to the Base Case. This lower use of oil would extend the supply of oil for a short period of time, but eventually an alternative to conventional oil would still need to be employed. That is what the next two cases address.

\section{Case 3}

Alternative fuels will become attractive as the price of oil increases caused by the peaking of world oil production. If both world oil and domestic natural gas production peak within the next 30 years, some alternative fuels will have to fill the light vehicle fuel gap that will develop even with the stable fuel use of fuel, as assumed by Case 1.

In this case, the fuel economies of Case 1 are achieved and ethanol vehicles and hydrogen fuel cell vehicles make up all the new light vehicle sales by 2050. But since these non-oil using vehicles do not comprise all the stock of vehicles in use, $2.2 \mathrm{mbpd}$ of oil is still being used in 2050. The ethanol use in 2050 is 3.7 mbpdge and the hydrogen use is 3.8 mbpdge (mbpd gasoline equivalent). Ethanol is used as E-85 which means that $15 \%$ of the volume is gasoline.

This case has oil use that is over $15 \mathrm{mbpd}$, or $88 \%$, lower than the Base Case in 2050 .

\section{Case 4}

In this case, the fuel economies of Case 2 are achieved and ethanol vehicles and hydrogen fuel cell vehicles make up all the new light vehicle sales by 2050. But since these non-oil using vehicles do not comprise all the stock of vehicles in use, $1.5 \mathrm{mbpd}$ of oil is still being used in 2050 . The ethanol use in 2050 is 2.6 mbpdge and the hydrogen use is 2.9 
mbpdge. The higher fuel economy values in the case mean that less of the low carbon fuels have to be produced. The savings of oil by 2050 are nearly $16 \mathrm{mbpd}$ in this case.

\section{Comparison with Other Fuel Economy Projections}

Figure 6 compares average new car mpg for the highest mpg case (Case 4) with some other mpg projections or targets that have appeared recently. The MIT projections ${ }^{13}$ have a low value (43 mpg) that represents what the analysts think the conventional car can achieve using gasoline. The MIT high value (94 mpg) is an advanced fuel cell car operating on hydrogen. The Union of Concerned Scientists projection ${ }^{14}$ has a low new car fuel economy in 2020 (43 mpg, which is an average of their small and large car estimates). This represents a first stage in evolutionary technology development $(10 \%$ reduction in aerodynamic drag, 20\% reduction in rolling resistance, $10 \%$ reduction in weight, variable valve control, 4-valve-per-cylimnder, integrated starter-generator, and continuously variable transmission).

\section{Figure 6: Alternative Car MPG Projections}

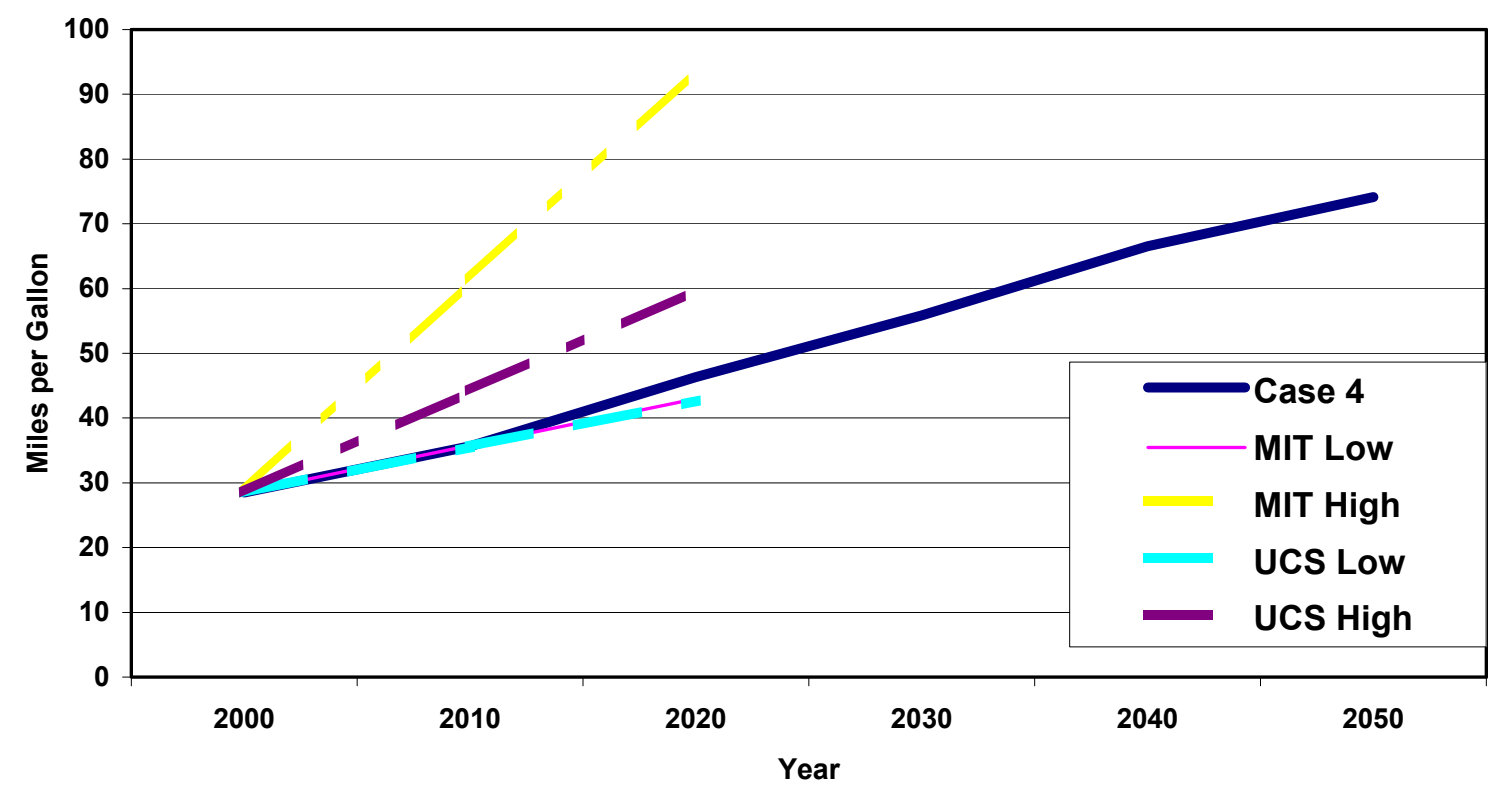

The USC high new car fuel economy (60 mpg) represents the technologies in the low case plus, $20 \%$ weight reduction, gasoline direct-injection, and hybridization.

The two low cases have new car mpg values that are very similar to the mpg in Cases 2 and 4 by 2020. The USC high case has a mpg value in 2020 that is not reached in Cases 2 and 4 until about 15 years later. Cases 2 and 4 need a new car mpg of 71 in 2050 that is lower than the $94 \mathrm{mpg}$ that MIT feels the hydrogen fuel can achieve.

The CAFÉ study conducted by the National Academy of Sciences ${ }^{15}$ said that light vehicle fuel economies in the 30 to $35 \mathrm{mpg}$ range were possible by 2015 . These mpg levels would be below all the 2015 mpg values shown in Figure 6. 


\section{The Importance of High MPG Vehicles}

It will be necessary to have vehicles with very high fuel economy to achieve the targets for the cases described above. There are, however, diminishing returns from mpg gains. For example, the fuel savings achieved from doubling fuel economy are $75 \%$ of the savings achieved from tripling fuel economy.

We know that there always is a distribution of vehicles with respect to fuel economy. In 2000 , the average light truck had a fuel economy of $20.4 \mathrm{mpg}$, but the seven classes that comprise light trucks ranged in mpg from 17.5 for large SUVs to 23.8 for small SUVs. ${ }^{16}$

To illustrate the need for very high mpg vehicles, assume that we want to double the fuel economy of new vehicles from $20 \mathrm{mpg}$ to $40 \mathrm{mpg}$ and we have only three options: 20,40 , and $60 \mathrm{mpg}$ vehicles. If we could get all new vehicles to reach $40 \mathrm{mpg}$, we would meet our goal. But if $10 \%$ of the new vehicles remained at $20 \mathrm{mpg}$, we would need $30 \%$ of the vehicles to be $60 \mathrm{mpg}$ and $60 \%$ to be $40 \mathrm{mpg}$. If $20 \%$ of the new vehicles stayed at 20 $\mathrm{mpg}$, the $40 \mathrm{mpg}$ average would require that $60 \%$ are $60 \mathrm{mpg}$ vehicles and $20 \%$ are 40 $\mathrm{mpg}$ vehicles. The highest share of $20 \mathrm{mpg}$ vehicles we could have and still reach a 40 mpg average is $25 \%$. In this case, the remaining $75 \%$ of the vehicles would have to get 60 mpg.

This shows how important it will be to minimize or reduce the share of vehicles that make no fuel economy improvements.

\section{SUMMARY}

Oil dependency and oil supply concerns have made it necessary to focus on light vehicle oil use now and for several decades to come. The transportation choices that people make in the near future will greatly impact the degree to which these oil concerns are dealt with. The oil used in the four cases is compared to the Base Case oil use in Figure 7. As expected, cases 3 and 4 show dramatic reductions in oil use while cases 1 and 2 show more moderate reductions. The introduction of alternative fuels, such as ethanol and hydrogen, are responsible for the differences, demonstrating the prominent role that these fuels and technologies may play in the future. 
Figure 7: U.S. Light Vehicle Oil Use

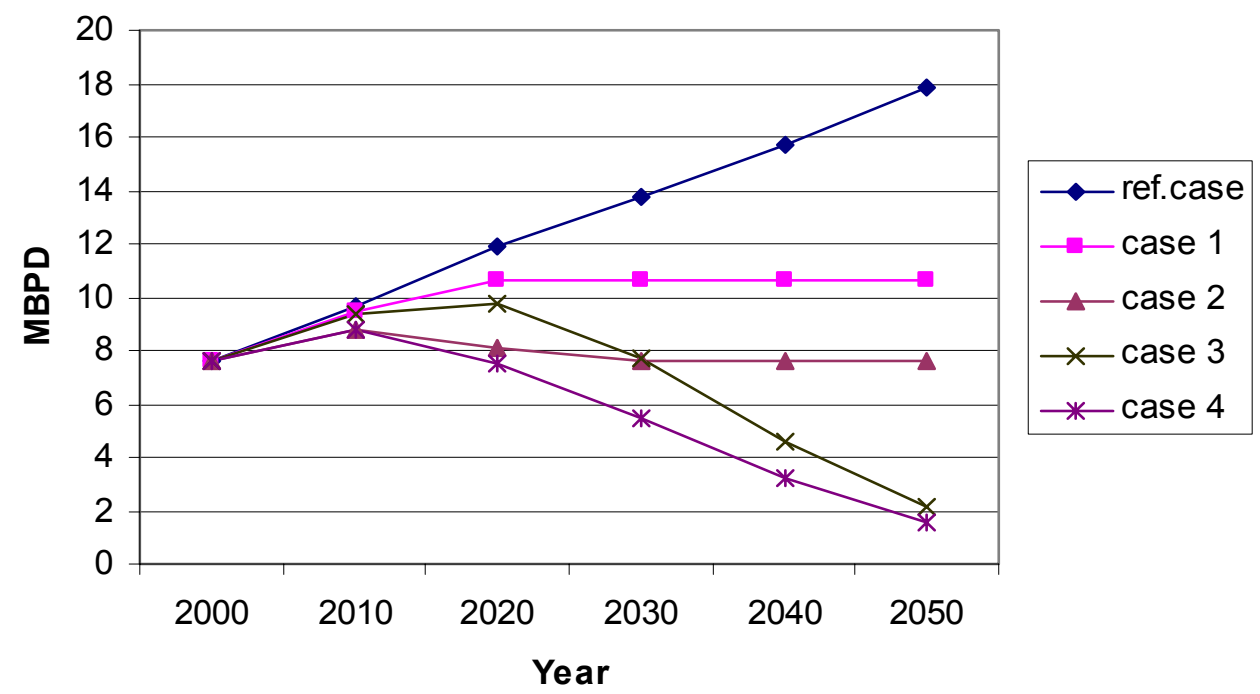

The carbon reductions for the four cases follow the same pattern as the oil reductions.

To achieve these very significant oil and carbon reduction figures, light vehicles have to become as efficient as shown in Figure 8. To attain the stabilization of carbon concentrations in the environment, it is necessary for carbon emissions to continually trend downward. This would require carbon reductions from the replacement of fossil fuels with renewables and/or low carbon hydrogen as done in Cases 3 and 4.

Figure 8: New Car MPG

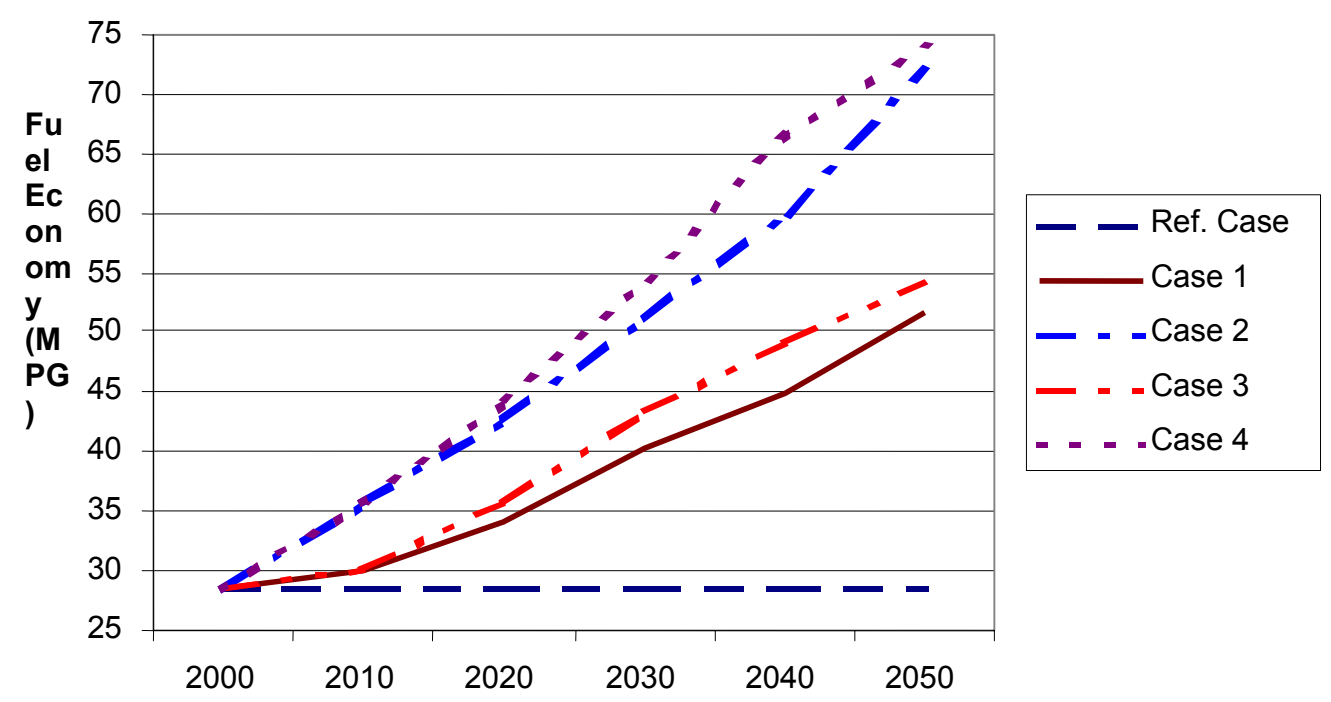

New cars are a little more efficient in Cases 3 and 4 relative to Cases 1 and 2 because when hydrogen is used, it is in a fuel cell vehicle that has slightly higher mpg than the vehicle it replaces. 
Are these new car mpg levels attainable in the years shown in Figure 7? And can comparable mpg gains be made in light trucks? The technical potential exists to reach these mpg levels. Two big issues will need to be addressed: can the incremental vehicle costs be reduced to acceptable levels and/or will consumer interest or public policy have to change?

\section{CONCLUSION}

The potential peaking of world conventional oil production and the possible imperative to reduce carbon emissions will put great pressure on vehicle manufacturers to produce more efficient vehicles, on vehicle buyers to seek them out in the marketplace, and on energy suppliers to develop new fuels and delivery systems.

Four cases for stabilizing or reducing light vehicle fuel use, oil use, and/or carbon emissions over the next 50 years were presented. The mpg targets for new cars and light trucks require that significant advances be made in developing cost-effective and very efficient vehicle technologies. With the use of alternative fuels that are low in carbon, oil use and carbon emissions can be reduced even further. Neither alternative fuels nor improved fuel efficiency alone can meet the toughest targets that might be set for light vehicles in terms of oil reductions or carbon emission reductions. To meet these ambitious targets, a combination of substantial improvements in fuel efficiency and new fuel technologies will be required. 


\section{REFERENCES}

${ }^{1}$ Future U.S. Highway Energy Use: A Fifty Year Perspective", Alicia Birky et al, at the Office of Transportation Technologies web site: http://www.ott.doe.gov/future_highway.shtml

${ }^{2}$ A summary of some of the peaking projections is at the "hubbertpeak" web site (http://www.hubbertpeak.com/curves.htm).

${ }^{3}$ Moore, Jim, "Natural Gas Availability", TA Engineering, Inc., 2001, draft.

${ }^{4}$ Greene, David, and Tishchishyna, N, “The Costs of Oil Dependence: A 2000 Update”, Transportation Quarterly, Vol. 55, No.3, 2001.

${ }^{5}$ Tien Nguyen, Office of Transportation Technologies, DOE, memo, September 7, 2001.

${ }^{6}$ EIA, Monthly Energy Review, July 2001, Table 1.10.

${ }^{7}$ John Maples, currently working for EIA, developed the first version of the VISION spreadsheet model in 1999 when a member of the OTT laboratory analytic team. Anant Vyas, Argonne National Laboratory, extensively revised the model in 2001. Documentation of the model was provided by Margaret Singh in early 2002 .

${ }^{8}$ EPA, "Light-Duty Automotive Technology and Fuel Economy Trends 1975 Through 2001", EPA420R01-008, September 2001. http://www.epa.gov/otaq/cert/mpg/fetrends/r01008.pdf

9 “Highway Statistics Summary to 1995", Federal Highway Administration, U.S. Department of Transportation, July 1997.

${ }^{10}$ Highway Statistics Summary to 1995, Federal Highway Administration, U.S. Department of Transportation, July 1997 and 2000 data from the DOT web site.

${ }^{11}$ EIA, “Annual Energy Outlook 2002”, DOE/EIA-0383 (2002), December 2002.

${ }^{12}$ David Greene, Oak Ridge National Laboratory, and others estimate the long-run rebound effect to be about 20\% in "Fuel Economy Rebound Effect for U.S. Household Vehicles", The Energy Journal, Volume 20, Number 3, 1999.

${ }^{13}$ Weiss, Malcolm, et al, “On the Road in 2020”, MIT EL 00-003, October 2000.

14 "Drilling in Detroit", David Friedman et al, Union of Concerned Scientists, June 2001.

${ }^{15}$ National Research Council, NAS, "Effectiveness and Impact of Corporate Average Fuel Economy (CAFE) Standards", July 31, 2001, draft.

${ }^{16}$ Davis, Stacy, "Transportation Energy Data Book", Edition 21, Oak Ridge National Laboratory, September 2001at: http://www-cta.ornl.gov/data/tedb21/Edition21Chapter07.pdf 